\author{
Рита Джулиани \\ Римский Университет «Сапьенца», Италия \\ giulianir@tiscali.it
}

Rita Giuliani

Sapienza - University of Rome (Italy)

giulianir@tiscali.it

\title{
ОБРАЗЫ ИТАЛИИ П. П. МУРАТОВА - ЕДИНСТВЕННЫЙ В СВОЕМ РОДЕ ШЕДЕВР РУССКОЙ ЛИТЕРАТУРЫ
}

\section{PAVEL MURATOV'S OBRAZY ITALII - A UNIQUE MASTERPIECE OF RUSSIAN LITERATURE}

\begin{abstract}
В статье анализируется жанровое своеобразие шедевра Павла Муратова Образы Италии (1911-1912), которое сделало его книгу уникальным явлением современной русской литературы. Счастливо соединяя в себе тенденции различных литературных жанров, произведение Муратова разительно отличается от текстов, формирующих корпус русско-итальянского травелога, блеском и отточенностью стиля, лиризмом, обширными познаниями автора в истории искусства. Опираясь на образцы английской эстетической критики, Муратов, «русский европеец», обладающий ренессансной многогранностью мышления, наследник традиции русской италофилии, обогатил русскую и европейскую литературу оригинальнейшим произведением, которое стало одним из самых выразительных явлений так называемого «русского Ренессанса» начала XX в.
\end{abstract} нессанс.

Ключевые слова: П. П. Муратов, Образы Италии, уникальность, русский Ре-

The article analyzes the genre peculiarities of Pavel Muratov's masterpiece, Obrazy Italii (Images of Italy, 1911-1912), that render the book unique in Russian literature of the time. As a successful hybridization of various literary genres, the work stands out from contemporary Russian counterparts for its brilliant incisive style, lyricism, and competence in the study of art history. Drawing on models of English aesthetic criticism, the 'Russian European' Muratov, a man of Renaissance versatility and heir to the tradition of Russian Italophilia, leaves to Russian and Western culture a very original work that is one of the most representative cultural events of the so-called 'Russian Renaissance' of the early 20th century.

Keywords: P. P. Muratov, Obrazy Italii, uniqueness, 'Russian Renaissance'.

Павел Муратов (1881-1950) - человек многосторонних интересов, писатель, искусствовед, переводчик, публицист, военный историк - обя- 
зан своей славой прежде всего книге Образы Италии, самому знаменитому и самому оригинальному его произведению. Шумный успех вышедшей в 1911-1912 гг. в двух томах книги был обусловлен и высочайшими художественными достоинствами ее текста, и тем чарующим воздействием, которое книга имела на русского читателя, влюбленного в итальянскую тему русской литературы на протяжении всего классического периода ее развития. Сразу вслед за первым вышло второе издание книги (19121913), а в 1924 г. издательство русского эмигранта в Берлине 3. И. Гржебина выпустило и третье, полное издание Образов в 3 -х томах ${ }^{1}$.

Появление Образов Италии стало событием в русской культуре этого времени. Книга дала мощный импульс русской культуре: она вольно или невольно воспитывала и развивала эстетический вкус читателя и способствовала «перечитыванию» Италии в свете картин и внезапных озарений ее автора ${ }^{2}$. Такому успеху способствовала и абсолютная жанровая новизна произведения, чье своеобразие принципиально несводимо к известным и мгновенно идентифицируемым жанровым традициям: в зачине предисловия сам автор подчеркнул особенности ее жанра: «Эта книга является опытом изображения Италии: ее городов и пейзажей, ее исторического и художественного гения. Удержанные здесь образы Италии можно назвать также воспоминаниями» (Муратов 1911: 1). В 1993 г. В. Н. Гращенков в послесловии к Образам Италии, отметил, что «<... давнюю литературную традицию путевых записок Муратов соединил с приемами английского художественно-критического эссеизма и методологическими достижениями нового европейского искусствознания» (1993: 313). И для лучшего понимания жанрового своеобразия книги Муратова тем более важно определить жанровые традиции, на которые он опирался, и выявить их конструктивные элементы.

Как известно, стиль и нарративные стратегии Муратова испытали влияние не столько русских образцов подобного жанра. В предисловии к первому изданию Муратов открыто назвал свои претексты: «<..> у английских писателей мне не только пришлось учиться Италии, но и учиться писать об Италии. Высокие примеры Дж. А. Симондса и Уолтера Патэра были у меня всегда перед глазами» (1911: 15). Эти писатели дали Муратову отсутствовавшие в русской литературной традиции новые формальные, композиционные и стилевые модели и своим авторитетом укрепили и без того свойственный личности Муратова эстетизм и предпочтительную склонность к отдельным эпохам итальянского искусства, таким как Кватроченто и искусство «примитивов»³. Именно из английской традиции Муратов почерпнул прием оригинальной контаминации разных жанровых тенденций. Тексты Патера стали образцом блестящего и увлекательного

\footnotetext{
1 Муратов 1924. В России это полное издание было опубликовано только после распада СССР: Муратов 1993-1994; Муратов 1994.

2 См. Муратова 2014: 161; Панфилова 2015: 5-8.

3 Об английской эстетической критике, см.: Praz 2013: 199-329.
} 
стиля - но от беспокойства и нервной дрожи викторианской эпохи английской культуры и самого Патера Муратов бесконечно далек. Из работ Вернон Ли в книгу Муратова пришла склонность к поискам и описанию «гения места». С английской эссеистикой Муратова роднит и молниеносная интуиция - но ее стиль, несколько графичный, ему чужд. И уж совсем отсутствует в стиле Муратова свойственная Симондсу одержимость эротикой.

Стиль Муратова отличается от стиля англосаксонской эстетической критики своей страстностью и солнечным энтузиазмом, как если бы он был защищен от декадентствующего эстетизма своих литературных претекстов самим «щитом» романтического итальянского мифа русской литературы. Его книга стала живительной русской прививкой к жанровой традиции и рафинированной чувствительности декаданса, гармоничным сплавом достоинств английской эстетической критики и мощной русской интенции вечных поисков истины.

И в том, что касается жанра травелога, которому писатель очевидно обязан, его образцы тоже восходят к европейской традиции: это Стендаль, Грегоровиус, Гёте. Итинерарий путешествия Муратова в первом издании воспроизводит, с некоторыми вариациями, канонический итинерарий так называемого Grand Tour. Беря свое начало в Венеции, он включает посещение Падуи, Феррары, Болоньи, Равенны, Флоренции ${ }^{4}$ и других тосканских городов, Рима и Кампаньи ${ }^{5}$, Неаполя, Помпей, Амальфи, Равелло, Пестума, Палермо и других городов и местностей Сицилии (Сираузы, Агригент, Этна). В издании же 1924 г. итинерарий расширен за счет посещения Умбрии (Ассизи, Перуджа) и - на севере Италии - Пармы, Милана и других городов Ломбардии. В результате итинерарий Муратова, представленный в третьем издании, почти полностью накладывается на маршрут Гёте, который, однако, отправившись из баварского Мюнхена, вступил в Италию через Трентино. Как и Гёте, Муратов «проскочил» Сорренто, руководствуясь достаточно своеобычными для русского путешественника критериями выбора. Как и для Гёте, и для многих интеллигентных поклонников Grand Tour, путешествие имеет для Муратова характер инициации, ведущей к более глубокому пониманию красоты и искусства. Эта инициация осуществляется посредством молниеносных озарений в длящемся откровении красоты и истины искусства и жизни. И в отличие от своих нарративных моделей Образы Италии абсолютно современны и по своему увлекательному образному стилю, и по свободе нарратива от общепризнанных литературно-критических стереотипов.

С точки зрения профессиональной путешествие Муратова становится своего рода воспитательным романом - писатель возвращается из него зрелым и авторитетным искусствоведом. Путешествие становится лабора-

\footnotetext{
${ }^{4}$ В первом издании отсутствует глава «Пленный дух», посвященная Микеланджело, и параграф о Понтормо в главе «Бронзино и его время».

5 В первом издании нет части, посвященной Лациуму, одной из самых прекрасных и оригинальных частей книги.
} 
торией ученого, который апробирует в Италии свою компетентность, интуицию, ви́дение искусства - и в контакте с шедеврами многих столетий вырабатывает собственную концепцию первоначал и эволюции художественных форм.

Говорить об образности применительно к историко-критическому этюду — это достаточно нетипично, поскольку образность - это неотъемлемое свойство поэзии. Образность стиля Муратова обладает теми самыми качествами, которые Роже Кайлуа считает неотъемлемым признаком поэтического образа: у нее есть собственная энергия, она «верна и предполагаема» и как бы колеблется между «очевидностью и неожиданностью» (Caillois 1946: 78). Словесная ткань текста пронизана неожиданными вспышками этой образности, которая абсолютно соответствует признакам, упомянутым Кайлуа: «и сама пыль спит крепким сном, и ветер напрасно будит ее» (Муратов 1993-1994: Т. 1, 226). Желая придать своему стилю эту образность, писатель постоянно использует технику экфрасиса, применяя ее не только к описанию произведений невербальных искусств, но и к описанию видов, пейзажей, к воссозданию словесных портретов воображаемых или реально встреченных людей. Его манера письма имеет достоинство живописности, его хроматическая гамма обладает яркостью и насыщенностью цвета. Посредством образов он передает ощущение, чувство, очарование, ауру и дух посещаемых местностей, тем самым давая доказательство экстраординарной творческой и миметической силы своего воображения.

Грандиозную и гармоничную картину создает искусное сочетание образов, будь то лаконичная метафора («Даже акведуки кажутся здесь стадами, бегущими через пространства» — о Римской Кампанье; Там же: Т. 2, $100)$ или массовая сцена, жанровая картинка или описание памятника, пейзаж или биографический набросок, исторический эпизод или адресация к эмоциям. Визуальный компонент текста книги силен до степени самодостаточности, так что иллюстрации представляются драгоценным, но не строго необходимым дополнением к тексту. Образы вовлекают в рецепцию текста не только зрение, но и другие ощущения: обоняние, осязание, слух и даже вкус. Субъективно-личностный критерий их отбора и тот факт, что в основу книги легли воспоминания и впечатления путешествия, столь частотные в ее нарративе, позволяют рассматривать ее жанровую специфику на фоне автобиографических жанров - таких, как мемуарная литература и «эссеистика», и говорить об автобиографизме Муратова, подразумевая под этим термином метод писателя, переносящего в текст субъективные переживания (Медарич 1998: 5-6).

В статье 1926 г. «Искусство прозы», излагая свою собственную теорию прозы, Муратов определил особенности так называемого «эссеизма». Согласно его суждению, историки, путешественники, мемуаристы, «эссеисты» сопрягают в своих произведениях «прозу повествовательную и описательную» и «кажутся нам уже совсем “художниками" по мастерству и изяществу языка, <...> “эссеисты” вообще доказывают, что мысль может 
быть таким же элементом художественного делания, как и слово» (Муратов 1926: 241). И в частности, «всякий мемуарист стремится восстановить былое, воскресить жизнь. В рассказе его должна быть для этого особая степень жизненной заразительности» (Там же. Курсив Муратова). Этот критерий — «заразительность» - Муратов унаследовал от Толстого, утверждавшего в статье «Что такое искусство?»: «Признак, выделяющий настоящее искусство от поддельного, есть один несомненный - заразительность искусства» (Толстой 1951: 148).

Все эти нарративные элементы легко обнаружить в Образах Италии - специфика муратовской манеры повествования самым счастливым образом предвещает его же собственную теорию прозы.

В книге Муратова ясности и утонченности образов сопутствует точность выражений, особенно это очевидно в финальных фрагментах глав: «Судьба заставила искусство сказать последнее слово в Риме гравюрами Пиранези. Содержанием этого последнего из процветавших в Риме великих искусств был пафос разрушения» (Муратов 1993-1994: Т. 2, 96); «маска, свеча и зеркало: вот образ Венеции XVIII века» (Там же: Т. 1, 64).

Сверкающий веер образов скреплен как печатью негромким титулом, почти что формулой скромности (topos modestiae). И тем не менее, этот титул весьма проницателен, поскольку он освобождает автора от традиции записок-воспоминаний об итальянском путешествии и предзнаменует дистанцирование от жанра травелога, обнаруживая желание автора, руководствующегося собственными критериями выбора мест и произведений искусства, предложить читателю не столько систематическое изложение темы в ее полноте, сколько свою на нее точку зрения. Так, например, в части книги, повествующей о Риме, Муратов посвящает главу Мелоццо да Форли, но обходит молчанием творчество Караваджо.

Любовь Муратова к Италии заключена в тот период русской культуры начала XX в., в котором итальянский миф снова расцвел по всей Европе, будучи оживлен исследованиями по истории итальянского искусства таких писателей и ученых как Буркхард, Вёльфлин, Ампер, Вернон Ли, Патер, Беренсон, Вентури, Симондс.

Муратов смотрит на Италию под индивидуальным углом зрения, нетипичным для русской литературы той эпохи. В Италии он ищет следов гения нации, которым созданы бессмертные произведения искусства и дана жизнь культуре, оживившей Западную Европу. Он ищет и воссоздает дух минувших времен, закрепленный и сохраненный в различных художественных формах. В искусстве и в народной жизни Италии он выше всего ценит гармонию и витальность. Он любит бурлящую и бьющую через край жизнь народа - более всего это очевидно в главе, посвященной Неаполю, в которой Муратов возрождает традицию романтического неаполитанского мифа о «лаццарони» ${ }^{6}$ и не касается современной полнокровной неапо-

6 Об образе Неаполя в русской литературе эпохи романтизма, см. Лебедева, Янушкевич: 2014. 
литанской культуры за исключением нескольких строк, повествующих о народном театральном искусстве. Для него простой необразованный народ является носителем естественности не тронутого цивилизацией «италийского гения». Эта убежденность может показаться слишком руссоистской, но не забудем и о том, что в те времена около $70 \%$ итальянцев были неграмотными.

Муратов видит и переживает Италию как противоядие от торжествующей серости современности, как миф европейской интеллигенции о красоте и радости жизни. В Италии ему дорого всё: в каждом городе и местности, им посещенной, он ищет того, что уверило бы его в незыблемости их уникальной самоидентичности, отличающей эти места от общеитальянского контекста. И для каждой местности он находит особые слова и чувства. Встреча с Италией погружает его в солнечную эйфорию, приглушающую «русское уныние» и оставляющую лишь легкую вуаль меланхолии, которая временами окутывает повествование и провоцирует особую приверженность автора, иной раз склонного очаровываться упадком, к поэзии руин и к любовным описаниям закатов и переживанию магии вечера.

Казалось бы, жизнь современной Италии не должна быть видна под этим специфическим углом зрения, но это не так: паломник-любитель искусства неожиданно являет себя внимательным наблюдателем жизни молодой итальянской нации, способным уловить такие аспекты общественной жизни и политики, которые как правило остаются в тени у других русских литераторов, оставивших воспоминания о своих путешествиях по Италии. Муратову же принадлежат наблюдения, актуальные и для наших дней и временами даже пророческие. По поводу жизни Рима он замечает: «Строительная лихорадка кажется хронической болезнью новой Италии парламентов и муниципалитетов. Новые кварталы вырастают в Риме с такой быстротой, которая мало оправдывается какими бы то ни было необходимостями» (Там же: Т. 2, 72). И далее клеймит урбанистические новшества нового политического режима, разрушающие классический облик Рима. В неаполитанской главе книги его суждение о каморре не утратило своей актуальности и сегодня: «Неаполитанская каморра является, в сущности, установлением глубоко национальным. Она управляет городской жизнью при помощи преступлений. Действуя на воображение толпы, каморра завоевывает тем самым вечную популярность вместе с народным праздником и с народным театром» (Там же: Т. 2, 146).

Писатель не оставил в своей книге ни своего портрета, ни портретов своих спутников. Его облик, вырастающий из текста, не материален, а психологичен, эмоционален и духовно-интеллектуален. Этот облик не маркирован подчеркнутой «русскостью», а скорее какой-то неопределенной «северностью» («мы, северные люди...») и сближен с психологическим обликом человека той эпохи, которая утратила ценность самоидентичности, простоты и истины. Используя личное местоимение во множественном числе первого лица, Муратов разумеет под ним не столько себя и своих спутников, сколько свое поколение. 
Предисловие, в котором писатель реконструирует эволюцию итальянского мифа русской литературы, откровенно адресовано соотечественникам; но не так обстоит дело с текстом книги: напротив, он предназначен для более широкого круга, он ориентирован на подразумеваемого читателя - просвещенного космополита, «европеиста», которому хорошо внятны постоянные отсылки к авторам и произведениям западноевропейской литературы, критики и науки.

Тем более необычным является тот факт, что Муратов, творец полных жизни итальянских пейзажей и рафинированных экфрастических описаний произведений искусства, практически не упоминает дорогих сердцу русского читателя пейзажей и произведений искусства, которые обрели бессмертие в произведениях русских художников и писателей. В его книге отсылки к русским реалиям вполне спорадичны (Степанов 2014) - положение вещей, абсолютно нетипичное для русско-европейского травелога, в котором явной или скрытой точкой отсчета и сопоставительным фоном неизменно является Россия. И в этом Муратов тоже предстает совершенно оригинальным - поскольку даже в Италии русских не оставляли мысли о далекой родине. Для Муратова, напротив, Италия дорога прежде всего тем, что она - своего рода лакмусовая бумага современного европейского типа сознания. И этим книга Муратова разительно отличается от итальянских мемуаров его современников - Василия Розанова, Бориса Зайцева, Бориса Грифцова, Николая Анциферова ${ }^{7}$, бледных по сравнению с Образами Италии.

И все же Образы Италии, как кажется, не создали традиции в русской словесности: в сущности, книга Муратова так и осталась «другой» в русле художественно-критической литературы эпохи. И одну из причин этого феномена несомненно следует вменить в вину советскому режиму, который на 70 лет блокировал ее распространение в России - но не в эмигрантской среде, где, впрочем, она тоже осталась не столько образцом, сколько мифом ${ }^{8}$. Другой причиной стали радикальные перемены, последовавшие за Первой мировой войной, которая завершила эпоху, навсегда упразднив привычки, изменив ментальность и иерархию культурных ценностей. И, наконец, это изменения, которые произошли в послевоенной Италии, вставшей на путь модернизации и индустриализации, что тоже способствовало побледнению итальянского мифа. Но последней и главной причиной инакости Образов Италии на фоне русской и даже европейской эссеистики, очерковой традиции и литературы путешествий стало то, что книга Муратова была и остается недостижимым и неповторимым уникальным явлением.

7 В качестве наиболее показательных случаев отмечу: Розанов 1909; Осоргин 1913; Грифцов 1914; Зайцев 1999: 256-284 («Италия»: очерки, опубликованные в разных издательствах между 1954 и 1962 г.); Анциферов 2016 (Н. П. Анциферов был в Италии в 19101914 гг.).

8 В беседе с писателем В. Карпиньским (2018: 33) И. Бродский именно так определил гений Муратова-эссеиста. 
На фоне русской литературы нарратив Образов Италии явно выделяется своей оригинальностью: оригинальна прежде всего своеобычность гармонического сплава эрудиции, яркой художественности повествовательной манеры, которая не характерна для литературы путешествий, и безусловно общепризнанного эстетического вкуса. Оригинален язык Муратова, которым он излагает основы истории и теории искусства, язык бесконечно далекий как от терминологии, так и от банальности академических трудов, ориентированный на язык современной писателю западноевропейской художественной эссеистики. Оригинальны страсть, энтузиазм, лирические порывы, сердечный восторг и внушительное количество упоминаемых историко-литературных и критических претекстов. Оригинальна глубина интерпретации итальянского мифа и элементов, из которых он слагается: искусство, история, пейзажи, города, специфика «италийского гения», архаические первозданные черты которого были еще доступны Муратову и высоко ценимы им на фоне того, что происходило в других странах. И совершенно вне стереотипов травелога было то, что Италия стала для Муратова своего рода мастерской, в которой из паломника выковался искусствовед.

В попытке определить своеобразие нарративной манеры Муратова прибегну к иноязычным терминам. В этой связи можно говорить о Stimmung (настроение, нем.), объекте постоянного стремления Муратова в его страсти к познанию атмосферы и характера того или иного региона; о genius loci (гений места, лат.), глубинной прародительской энергии, которая определяет эти искомые характер и атмосферу; о hanter (в переносном смысле самозабвение, франц.) - термин, употребленный Марио Працем (2013: $304)$, которым он определил типологический признак повествовательной манеры Вернон Ли, свойственный также Муратову — то есть стремление позволить этой атмосфере овладеть душой, а душе - проникнуться ею, наконец, о непереводимом Sensucht (нем.) - неудовлетворенной ностальгии и томлении по Италии, которые подобно basso continuo звучат за текстом Муратова.

Обращусь также к понятию, в сущности, довольно чуждому для русской литературы: Ренессанс. Действительно, темперамент и многогранность Муратова периодически определяются этим понятием (Остойя 2008; Сарабьянов 2012): возможно, это и есть главная составляющая своеобразного стиля писателя, позволяющая, как утверждает Борис Зайцев, по неотъемлемому праву поставить его в один ряд с самыми крупными представителями того краткого расцвета русской культуры, который получил название русского Ренессанса и причислить его книгу к самым значительным произведениям этой золотой осени русской культуры: «В русской литературе нет ничего равного по артистичности переживания Италии, по познаниям и изяществу исполнения. Идут эти книги [Образы Италии - Р. Дж.] в тон и с той полосой русского духовного развития, когда культура наша, в некоем недолгом “ренессансе” или “серебряном веке”, выходила из провин- 
циализма конца XIX столетия к краткому, трагическому цветению начала XX-го» (Зайцев 1999: 215-216).

«Чувствительный путешественник», искатель гения места и дуновения воздуха прошедших эпох, Муратов одновременно уловил и дух своего времени и своей литературно-художественной культуры, создав в Образах Италии гармоничный синтез наук и стилей, который как в зеркале отразил всепоглощающую жажду синтеза искусств, свойственную его эпохе. Благодаря этому своеобразному и счастливому синтезу, который позволил ему воссоздать минувшее, Муратов в совершенстве воплотил саму душу русской культуры первого десятилетия XX в. В настоящее время Образы Италии общепризнанно считаются своего рода квинтэссенцией утонченной русской культуры начала XX в., а их автор - ее классиком. Но при этом остается вопрос: как случилось то, что эта книга до сих пор не вошла в русский литературный канон (Джулиани 2019)?

Возникает и другой вопрос: если Образы Италии являются уникальным произведением русской словесности, что же в них специфически русского? Полагаю, что Муратова делает именно русским писателем неявная, но прочная связь с национальной культурной традицией. Его книга хранит генетическую память великого произведения, ознаменовавшего собой рождение новой русской литературы на рубеже XVIII и XIX в. Письма русского путешественника Н. М. Карамзина - тоже синтез разножанровых традиций эссеистики и литературы путешествий в автобиографическом повествовании - сформировали и воспитали вкус русского читателя. Кроме того, муратовское «чувство Италии», которое ознаменовано той же эмпатией и той же любовью вплоть до идеализации, заставляющей благосклонно относиться даже к национальным и местным недостаткам, вписывается в традицию русской литературы, идущую от Гоголя к Бродскому. Муратова, Гоголя и Бродского следует счесть величайшими италофилами русской культуры; они не только проникновенно любили Италию, но и глубоко понимали ее и сумели избавить ее образ от вековых клише литературы, ей посвященной. Гоголевская пронзительность чувства и чувствительность в отношении к Италии, равно как и культ гармонии и красоты, делают Муратова глубоко причастным к самому сердцу, к самой душе русской культурной и литературной традиции. Скажу больше: Образы Италии это самая прекрасная книга из всех, которые русская литература посвятила Италии.

Однако было бы неправомерно ограничивать значение Образов Италии только позицией в русской культуре, поскольку дыхание этой книги гораздо более мощно, так же, как и место, занимаемое ею в ряду великих книг об Италии, созданных западноевропейской словесностью9. В антоло-

9 Образы Италии были переведены на польский (Muratow 1972) и итальянский (Muratov 2019, Muratov 2021) языки. Английский перевод — в печати (Muratov 2022; Muratova 2021). 
гии похвальных слов Образам Италии и той роли, которую книга Муратова сыграла в русской и европейской культуре, некоторые кажутся мне особенно значимыми. Уильям Аллен, английский друг писателя и соавтор его последних трудов исторического характера ${ }^{10}$, после смерти писателя в 1950 г. написал: «Павел Павлович сделал для России то, что сделали Рёскин и Патер для английской культуры» ${ }^{11}$. А критик Клайв Джеймс пошел еще дальше, утверждая: «Как книга об итальянском Grand Tour [Образы Италии - Р. Джс.] не только непосредственно примыкают к традиции Гёте, Грегоровиуса, Буркхарда и Артура Симонса ${ }^{12}$, но и превосходят эти книги» (2007: 527).

Европейский масштаб и ценность Образов Италии исчерпывающе определены архимандритом Киприаном: ““Образы Италии” — это одно из свидетельств великого прошлого России, один из последних лучей ее безвременного заката. Вышедшая незадолго до 14 года, она явилась каким-то прощальным приветом той неповторимой нашей просвещенности и утонченности, по которой мы были настоящими европейцами» (2008: 161).

И может быть, именно неповторимое своеобразие этой книги, невозможность отнести ее к какой-то канонической жанровой традиции, ее счастливая и поистине гениальная гетерогенность и послужили причиной того, что шедевр Павла Муратова, «русского европейца», до сих пор остается вне русского литературного канона.

\section{ЛИТЕРАТУРА}

Анциферов Николай. Отчизна моей души. Воспоминания о путешествиях в Италию. Дарья С. Московская (сост.), Михаил Г. Талалай (ред.). Москва: Старая Басманная, 2016. Архиманрит Киприан (Керн). «“Образы Италии” Муратова». Возвращение Муратова. Om «Образов Италии» до «Истории кавказских войн». Герольд И. Вздорнов и Ксения М. Муратова (общ. ред.). Москва: Индрик, 2008: 160-161.

Гращенков Виктор. «П. П. Муратов и его “Образы Италии”». Муратов Павел. Образы Италии. Полное издание: $B 3$ m. Виктор Н. Гращенков (ред., коммент. и послесл). Москва: Галарт, T. I. 1993: 290-314.

Грифцов Борис. Рим. Москва: Типо-литорафия Т-ва И. Н. Кушнерев и Ко, 1914.

Деотто Патриция. «Библиография П. П. Муратова». Archivio italo-russo II/Pyccкo-итальянский архив II. Daniela Rizzi e Andrej Shishkin (a cura di). Salerno: Europa Orientalis, 2002: 365-394.

Джулиани Рита. «Павел Муратов, или инерция литературного канона». Известия Российской академии наук. Серия литературы и языка. Т. 78, 2 (2019): 1-4.

Зайцев Борис. «П. П. Муратов». Зайцев Борис. Собрание сочинений: $B 5$ m. Москва: Русская книга. Т. VI (доп). 1999: 214-220.

Карпиньский Войцех. «Разбойничьи книги и города. Часть вторая». Новая Польша 2 (2018): $33-36$.

Лебедева Ольга, Янушкевич Александр. Образы Неаполя в русской словесности XVIII первой половины ХІХ веков. Salerno: Europa Orientalis, 2014.

10 О библиографии Муратова, см. Деотто 2002.

11 Цит. по: Муратова 2014: 162.

12 Среди источников Образов Италии упомянуто также творчество Артура Симонса. 
Медарич Магдалена. «Автобиография/автобиографизм». Автоинтерпретация. Сборник статей. Аскольд Б. Муратов и Людмила А. Иезуитова (ред.). Санкт-Петербург: изд. С.-Петербургского ун-та, 1998: 5-32.

Муратов Павел. Образы Италии. Т. 1. Москва: Научное слово, 1911.

Муратов Павел. Образы Италии, Т. I-III, Лейпциг [Берлин]: изд. З. И. Гржебин, 1924.

Муратов Павел. Образы Италии. Полное издание: $B 3 \mathrm{~m}$. Виктор Н. Гращенков (ред., коммент. и послесл). Москва: Галарт. Т. І. 1993; Т. II-III. 1994.

Муратов Павел. Образы Италии. Василий М. Толмачёв (подгот. текста и послесл.). Москва: Республика, 1994.

Муратов Павел. «Искусство прозы». Современные Записки ХXIX (1926): 240-259.

Муратова Ксения. «Павел Муратов и Италия». Образы Италии в России - Петербурге Пушкинском доме. Андрей Б. Шишкин (ред.). Санкт-Петербург: изд. Пушкинского дома, 2014: 161-186.

Остойя Вера. «О Муратове в последние годы его жизни». Возвращение Муратова. Om «Образов Италии» до «Истории кавказских войн». Герольд И. Вздорнов и Ксения М. Муратова (общ. ред.). Москва: Индрик, 2008: 162.

Осоргин Михаил. Очерки современной Италии. Москва: Типо-литорафия Т-ва И. Н. Кушнерев и Ко, 1913.

Панфилова Марина. «Образы Италии в культуре Серебряного века». Вестник Томского государственного университета. Культурология и искусствоведение 3 (19) (2015): $5-16$.

Розанов Василий. Итальянские впечатления. Санкт-Петербург: изд. А. С. Суворина, 1909.

Сарабьянов Дмитрий. «Грани многополярного таланта». Наше наследие 104 (2012), <http:// nasledie-rus.ru/podshivka/10404.php. > 13.05.2021.

Степанов Андрей. «Образы России в “Образах Италии” Павла Муратова». Образы Италии в России - Петербурге - Пушкинском доме. Андрей Б. Шишкин (ред.). Санкт-Петербург: изд. Пущкинского дома, 2014: 187-191.

Толстой Лев. «Что такое искусство?». Толстой Лев. Полное собрание сочинений: $B 90 \mathrm{~m}$. T. 30. Москва: Художественная литература. 1951: 27-203.

Caillois Roger. Vocabulaire esthétique. Paris: Fontaine, 1946.

James Clive. «Paul Muratov». James Clive. Cultural Amnesia. Necessary Memories from History and the Arts. New York-London: W. W. Norton \& Company, 2007: 524-532.

Muratow Pawel. Obrazy Włoch. T. I-II. Pawel Hertz (tłum., przypis. i posł.). Warszawa: Państwowy Institut Wyd.: 1972.

Muratov Pavel. Immagini dell'Italia. T. 1. Rita Giuliani (a cura di), Alessandro Romano (trad.) Katja Petrowskaja (saggio). Milano: Adelphi, 2019. T. 2. Rita Giuliani (a cura di), Alessandro Romano (trad.). Milano: Adelphi, 2021.

Muratov Pavel. Images of Italy. Xenia Muratova (pref.), J. Presto (introd.), Lena M. Lencek (transl., notes \& afterw.). Evanston: Northwestern University Press, 2022.

Muratova Xenia. «Overview of Muratov Studies and Activities of the "Centro Internazionale di Studi Pavel Muratov"». Rita Giuliani (a cura di). Letture Muratoviane III. Studi in memoria di Хепia Muratova/Tретьи Муратовские Чтения. Сборник научных статей памяти К. М. Муратовой. Roma: Lithos, 2021: 87-95.

Praz Mario. Il patto col serpente. Paralipomeni di «La carne, la morte e il diavolo nella letteratura romantica». Milano: Adelphi, 2013.

\section{LITERATURE}

Anciferov Nilokaj. Otchizna moej dushi. Vospominanija o puteshestiviyah v Italiyu. Dar'ya S. Moskovskaya (sost.), Mikhail G. Talalay (red.). Moskva: Staraya Basmannaya, 2016.

Arhimandrit Kiprian (Kern). «"Obrazy Italii” Muratova». Vozvrashchenie Muratova. Ot «Obrazov Italii» do «Istorii kavkazkih vojn». Gerol'd I. Vzdornov i Kseniya M. Muratova (obshch. red.). Moskva: Indrik, 2008: 160-161.

Caillois Roger. Vocabulaire esthétique. Paris: Fontaine, 1946. 
Deotto Patrizia. «Bibliografiya P. P. Muratova». Archivio italo-russo II/Russko-ital' janskij archiv II. Daniela Rizzi e Andrey Shishkin (a cura di). Salerno: Europa Orientalis, 2002: 365-394.

Giuliani Rita. «Pavel Muratov, ili inerciya literaturnogo kanona». Izvestiya Rossijskoj akademii nauk. Seriya literatury i yazyka T. 78, 2 (2019): 1-4.

Grashchenkov Viktor. «P. P. Muratov i ego "Obrazy Italii”». Muratov Pavel. Obrazy Italii. Polnoe izdanie: $V 3 t$. Viktor N. Grashchenkov (red., komment. i poslesl.). Moskva: Galart, T. I. 1993: 290-314.

Grifcov Boris. Rim. Moskva: Tipo-litografiya T-va I. N. Kushnerev i Ko, 1914.

James Clive. «Paul Muratov». James Clive. Cultural Amnesia. Necessary Memories from History and the Arts. New York-London: W. W. Norton \& Company, 2007: 524-532.

Karpiński Wojciech. «Razbojnich'i knigi i goroda. Chast' vtoraya». Novaya Pol'sha 2 (2018): $33-36$.

Lebedeva Ol'ga, Yanushkevich Aleksandr. Obrazy Neapolja v russkoj slovesnosti XVIII — pervoj poloviny XIX vekov. Salerno: Europa Orientalis, 2014.

Medaric Magdalena. «Avtobiografiya/avtobiografizm». Avtointerpretaciya. Sbornik statej. Askol'd B. Muratov i Lyudmila A. Iezuitova (red.). Sankt-Peterburg: izd. S.-Peterburgskogo un-ta, 1998: 5-32.

Muratov Pavel. Obrazy Italii. T. 1. Moskva: Nauchnoe slovo, 1911.

Muratov Pavel. Obrazy Italii. T. I-III. Leipzig [Berlin]: izd. Z. I. Grzhebin, 1924.

Muratov Pavel. «Iskusstvo prozy». Sovremennye Zapiski XXIX (1926): 240-259.

Muratov Pavel. Obrazy Italii. Polnoe izdanie. $V 3 t$. Viktor N. Grashchenkov (red., komment. i poslesl). Moskva: Galart, T. I. 1993; T. II-III. 1994.

Muratov Pavel. Obrazy Italii. Vasiliy M. Tolmachev (podgot. teksta i poslesl.). Moskva: Respublika, 1994.

Muratow Pawel. Obrazy Włoch. T. I-II. Pawel Hertz (tłum., przypis. i posł.). Warszawa: Państwowy Institut Wyd., 1972.

Muratov Pavel. Immagini dell'Italia. T. 1. Rita Giuliani (a cura di), Alessandro Romano (trad.), Katja Petrowskaja (saggio). Milano: Adelphi, 2019. T. 2. Rita Giuliani (a cura di), Alessandro Romano (trad.). Milano: Adelphi, 2021.

Muratov Pavel. Images of Italy. Xenia Muratova (pref.), J. Presto (introd.), Lena M. Lencek (transl., notes \& afterw.). Evanston: Northwestern University Press, 2022.

Muratova Xenia. «Overview of Muratov Studies and Activities of the "Centro Internazionale di Studi Pavel Muratov"». Rita Giuliani (a cura di). Letture Muratoviane III. Studi in memoria di Xenia Muratova/Tret'i Muratovskie Chteniya. Sbornik nauchnych statej pamjati K. M. Muratovoj. Roma: Lithos, 2021: 87-95.

Muratova Kseniya. «Pavel Muratov i Italiya». Obrazy Italii v Rossii - Peterburge - Pushkinskom dome. A. B. Shishkin (red.). Sankt-Peterburg: izd. Pushkinskogo doma, 2014: 161-186.

Osorgin Mihail. Ocherki sovremennoj Italii. Moskva: Tipo-litografiya T-va I. N. Kushnerev i Ko, 1913.

Ostoja Vera. «O Muratove v poslednie gody ego zhizni». Vozvrashchenie Muratova. Ot «Obrazov Italii» do «Istorii kavkazkih vojn». Gerol'd I. Vzdornov i Kseniya M. Muratova (obshch. red.). Moskva: Indrik, 2008: 162.

Panfilova Marina. «Obrazy Italii v kul'ture Serebrjanogo veka». Vestnik Tomskogo gosudarstvennogo universiteta. Kul'turologiya i iskusstvovedenie 3 (19) (2015): 5-16.

Praz Mario. Il patto col serpente. Paralipomeni di «La carne, la morte e il diavolo nella letteratura romantica». Milano: Adelphi, 2013.

Rozanov Vasilij. Ital' janskie vpechatleniya. Sankt-Peterburg: izd. A. S. Suvorina, 1909.

Sarab'yanov Dmitrij. «Grani mnogopolyarnogo talanta». Nashe nasledie 104 (2012), <http:// nasledie-rus.ru/podshivka/10404.php.> 13.05.2021.

Stepanov Andrej. «Obrazy Rossii v “Obrazah Italii” Pavla Muratova». Obrazy Italii v Rossii Peterburge - Pushkinskom dome. Andrey B. Shishkin (red.). Sankt-Peterburg: izd. Pushkinskogo doma, 2014: 187-191.

Tolstoj Lev. «Chto takoe iskusstvo?». Tolstoj Lev. Polnoe sobranie sochinenij: V 90 t. T. 30, Moskva: Hudozhestvennaya literatura, 1951: 27-203.

Zajcev Boris. «P. P. Muratov». Zajcev Boris. Sobranie sochinenij: V 5 t. Moskva: Russkaya kniga. T. VI (dop.). 1999: 214-220. 
Рита Ђулијани

СЛИКЕ ИТАЛИЈЕ П. П. МУРАТОВА - ЈЕДИНСТВЕНО РЕМЕК-ДЕЛО

РУСКЕ КЮИЖЕВНОСТИ

Резиме

У чланку се анализира жанровска оригиналност ремек-дела Павла Муратова Слике Ийалије (1911-1912), које је његову књигу учинило јединственим феноменом савремене руске књижевности. Успешно комбинујући тенденције различитих књижевних жанрова, Муратовљево дело се упечатљиво разликује од текстова који чине корпус руско-италијанског путописа, сјајем и истанчаношћу стила, лиричношћу и опсежним знањима аутора из области историје уметности. Ослањајући се на примере из енглеске естетске критике, Муратов, „руски Европљанин“ са ренесансном свестраношћу мишљења, наследник традиције руске италофилије, обогатио је руску и европску књижевност најоригиналнијим делом, које је постало један од најупечатљивијих феномена такозване „руске ренесансе“ са почетка XX века.

Кључне речи: П. П. Муратов, Слике Ийалије, јединственост, руска Ренесанса. 